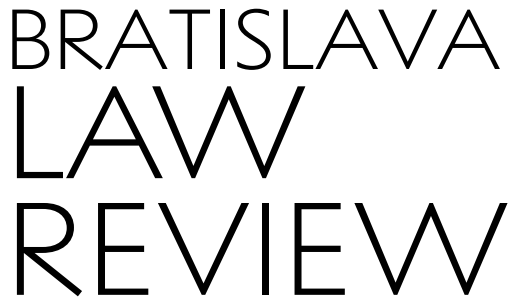

\title{
PROBLEMATIC ASPECTS OF JUDICIAL PROTECTION AGAINST THE INACTION OF ADMINISTRATIVE AUTHORITIES IN THE CZECH REPUBLIC / Kateřina Frumarová
}

\author{
doc. JUDr. Kateřina Frumarová, Ph.D \\ Associate Professor \\ Faculty of Law of Palacky University \\ in Olomouc \\ Tř. 17. listopadu 8 \\ 77111 Olomouc \\ Czech Republic \\ katerina.frumarova@upol.cz \\ ORCID: 0000-0001-5886-1645
}

Submitted: 09 July 2021

Accepted : 27 October 2021

Published : 30 December 2021

\begin{abstract}
One of the three most important types of actions in the Czech administrative judiciary is the action for protection against the inaction of an administrative body. Judicial protection follows on from the protection within the administrative proceedings (according to the Administrative Procedure Code). ${ }^{1}$ Its entrenchment in the Czech law in 2002 was a huge positive. Nevertheless, in practice there are some controversial issues or issues for discussion which relate to this action. The article analyses the essence of this action, its conditions and hearing in court. However, the main attention is paid to the problematic aspects of the action, both those regarding its legislation and those arising from the practice and case law relating to protection against administrative inaction.
\end{abstract}

Key words: Administrative authority; inaction; judicial protection; administrative judiciary; action for protection against inaction of administrative authority, Czech law

\section{Suggested citation:}

Frumarová, K. (2021). Problematic Aspects of Judicial Protection against the Inaction of Administrative Authorities in the Czech Republic. Bratislava Law Review, 5(2), 109-120. https://doi.org/10.46282/blr.2021.5.2.252

\section{INTRODUCTION}

The Code of Administrative Justice ${ }^{2}$ has brought to the Czech administrative judiciary a new means of protection against the inactivity of the Czech public administration. For the first time in the history of the Czech Republic, there is an action for protection against the inactivity of an administrative body. Until 31 December 2002, such a type of action was significantly absent in the Czech legal system, as was pointed out by the case law of the courts, including the Constitutional Court. The Constitutional Court has long replaced this role (of the administrative justice) and pointed this shortcoming out. " "The regulation of the administrative judiciary shows very serious constitutional deficits, where, above all, some activities of the public administration, as well as its possible inactivity, are not under the control of the judiciary." ${ }^{4}$ Until 1 January 2003,

\footnotetext{
${ }^{1}$ Act No. 500/2004 Coll, Administrative Procedure Code.

${ }^{2}$ Act No. 150/2002 Coll., Code of Administrative Justice.

${ }^{3}$ Constitutional Court of the Czech Republic, No. IV. ÚS 114/96 (25 September 1997), or the Constitutional Court of the Czech Republic, No. II. ÚS 507/05 (4 January 2006), etc.

${ }^{4}$ Constitutional Court of the Czech Republic, No. PI. ÚS 16/99 (27 June 2001). See also Varvařovský and Holeček (2001, pp. 9-10).
} 
the courts did not have the competence to provide protection against the inactivity of the public administration, although this is one of their traditional roles in a democratic state governed by the principle of the rule of law (Frumarová, 2012, p. 111).

The aim of this action is to ensure the protection of the public subjective rights of individuals and legal entities against the inactivity of the administrative authorities. The subject matter of the protection are specifically the subjective public rights deriving from Article 38 (2) and Article 36 (1) of the Charter of Fundamental Rights and Freedoms. ${ }^{5}$ It is a right to a hearing without undue delay (both in court proceedings and in administrative proceedings). When administrative authorities decide on matters falling under Article 6 of the Convention for the Protection of Human Rights and Fundamental Freedoms, their decision-making activity must also respect the requirement to decide the case "within a reasonable time" (i.e. one of the attributes of the right to a fair trial). ${ }^{6}$ For the needs and conditions of public administration, the principle of speed is explicitly enshrined and concretized in the Administrative Procedure Code ( $(6)$ as one of the so-called basic principles of the activity of administrative bodies (see Frumarová, 2003, pp. 1-13; Frumarová, Grygar, Pouperová, and Škurek, 2021, p. 20 et seq.; Skulová et al., 2020, p. 51 et seq.). The inactivity of an administrative body can therefore be generally defined as "an unlawful act of administrative bodies consisting of a breach of the statutory obligation to act, in particular to make a decision or take another act, in the statutory or reasonable time." (Srebalová, 2008, pp. 9-11; Frumarová, 2012, p. 36 et seq.). Similarly, the case law defines the inactivity as an objectively existing situation in which the relevant procedural acts were not performed within the time limits stipulated by law. ${ }^{7}$

Although the introduction of the complaint for failure to act was undoubtedly a welcome step and significantly improved the possibilities of the addressees of public administration to defend themselves against the inaction of administrative authorities, it should also be pointed out that the legal regulation of this complaint and its application in practice entail certain controversial or problematic aspects. Therefore, the main aim of this article is to identify the shortcomings of the legal regulation of the inaction complaint and to propose possible de lege ferenda solutions in the context of the analysis of this complaint. The first sub-area of the research will address the question of whether the dual concept of a judicial protection against the inaction, which is currently present in the Czech Republic, is appropriate and effective. Next, the article will address the question of whether the protection can be sought through this complaint even in the case of the inaction consisting of the failure to initiate administrative proceedings ex officio. This issue points to the fact that the possibility of judicial protection against inaction appears to be narrower than in the case of protection under the Administrative Procedure Code. In addition, other sub-issues will be analysed, such as the protection in the case of inaction by ministries and other central administrative authorities or the enforceability of court decisions concerning protection against inaction in practice.

In addressing the above-mentioned problems and issues, the author will rely primarily on the analysis of the existing legislation as well as the relevant case law of the courts. In particular, the decisions of the Constitutional Court and the Supreme

\footnotetext{
${ }^{5}$ Constitutional Court of the Czech Republic, No. III. ÚS 218/97 (4 December 1997), Constitutional Court of the Czech Republic, No. IV. ÚS 114/96 (25 September 1997), Constitutional Court of the Czech Republic, No. II. ÚS 366/96 (1 October 1997), or Constitutional Court of the Czech Republic, No. IV. ÚS 690/01 (27 March 2003). For more details see also Potěšil, Šimíček, et. al. (2014, p. 749 et seq.).

${ }^{6}$ Constitutional Court of the Czech Republic, No. I. ÚS 5/96 (5 November 1996), Constitutional Court of the Czech Republic, No. IV. ÚS 559/2000 (9 November 2000), or Constitutional Court of the Czech Republic, No. III. ÚS 687/04 (5 October 2005).

${ }^{7}$ Supreme Administrative Court of the Czech Republic, No. 2 Ans 14/2012 (10 December 2012).
} 
Administrative Court significantly complete the standard of a legal protection against public administration inaction in practice. Of course, the opinions and conclusions of legal doctrine will also be reflected. The article should introduce the Czech legal regulation of a judicial protection against inaction to the foreign expert community and, above all, provoke expert discussion on the optimal form of a legal regulation of this complaint. The principle of the speed of administrative proceedings as well as the effective judicial protection of the addressees of the public administration are among the basic standards of all European democratic states.

\section{THE ESSENCE AND GENERAL CHARACTERISTICS OF THE ACTION FOR PROTECTION AGAINST THE INACTION OF AN ADMINISTRATIVE AUTHORITY}

The purpose and function of the judicial protection against the unlawful acts of the public administration is to provide an effective means of defence at all times, regardless of the form in which the public administrative authority acts. ${ }^{8}$ This also applies to the substantive scope of three basic types of actions: actions against administrative decisions, actions for protection against the inaction of administrative authorities and actions against an unlawful interference of the administrative authorities. It is important that "any act of public administration directed against an individual and interfering with his or her rights or obligations is subject to the effective judicial review." ${ }^{\text {" }}$ We can say that the primary role in the system of these three actions is played by the action against the decision of the administrative body. The action for failure to act is a preparatory and auxiliary means in relation to the action against a decision. Its purpose is to force the administrative body to make a decision. As regards the relationship between the action for failure to act and the action against an interference, the action against an interference is subsidiary to the action for failure to act.

The legal regulation of this action can be found in $\S 79$ et seq. of the Code of Administrative Justice. This action may require the court to oblige the administrative authority to issue either a decision on the merits or a certificate. It clearly follows that this inaction action does not cover all possible forms of an administrative inaction. The legislator chose only two, which are, in their opinion, probably the most serious forms of inaction - namely failure to issue a decision on the merits and failure to issue a certificate.

Thus, the first problematic aspect is that in cases of other forms of public administration inaction, an inaction action cannot be brought. Initially, therefore, problems arose in practice as to how to proceed when the inaction of an administrative authority consists of something other than the failure to issue a decision or a certificate. The question was whether judicial protection should also be granted in such a situation and, if so, under which action. Ultimately, the situation had to be resolved by the courts themselves, in particular by the Supreme Administrative Court. It concluded that if the administrative authority's failure to act takes a form other than a failure to issue a decision on the matter or to issue a certificate, it must be regarded as unlawful interference and defended against by an action for interference. The Supreme Administrative Court has stated that "an action for interference protects against any other

\footnotetext{
${ }^{8}$ An action for protection against the inaction of an administrative authority is one of the modalities of the socalled general administrative action. Although it is not explicitly defined in the Czech legal order, a general administrative action can be defined as a legal instrument that opens the way to court for persons who are affected or threatened by the potentially tortious (unlawful) conduct of public administration officials (Pomahač, 2002, p. 100 et seq.).

${ }^{9}$ Supreme Administrative Court of the Czech Republic, No. 7 Aps 3/2008-98 (16 November 2010).
} 
acts of the public administration directed against an individual which are capable of affecting the sphere of his rights and obligations. (...) An interference may therefore also be an unlawful failure to act."10 Therefore, the Czech Republic currently has dual judicial protection against public administration inaction. Depending on the type of inaction, it is necessary to defend against it with an action for inaction or an action for interference. However, the question is whether it is appropriate to have two institutes (actions) for protection against the inaction and whether it is not more appropriate to simplify the system in this respect. From the point of view of both the addressees of public administration and the courts themselves, I consider it preferable to unify it.

The action for failure to act may only seek a decision in the matter or a certificate. It is therefore not possible to request merely in general terms that the administrative authority "should continue the proceedings" ${ }^{11}$ Nor is the court empowered to review decisions already taken in those proceedings. ${ }^{12}$ However, there are also situations in which the administrative authority is inactive even though it has taken a decision on the matter (Kühn, Kocourek, et al., 2019, p. 661). First, this may be the case where the administrative authority decides only part of the subject-matter of the proceedings. In such a situation, there is 'partial' inaction. ${ }^{13}$ And secondly, it may be a situation where the act by which the administrative authority has 'decided' is a null and void administrative act. ${ }^{14}$ Such an act is not a decision and is regarded as if it had not been issued (it has no legal effect). ${ }^{15}$

Another very problematic aspect of this action is whether it is possible to seek to initiate administrative proceedings ex officio. If in an administrative procedure initiated at the request of a party the administrative authority is inactive and considers that no procedure has been initiated, there is no doubt about the applicability of the action for inaction. If the administrative court finds that the party has duly initiated the administrative proceedings by its request, it shall, in its judgment, impose an obligation on the administrative authority to issue a decision on the matter (within a specified period of time). However, the situation is different for administrative proceedings initiated ex officio. These proceedings are always initiated by the administrative authority; the party to the proceedings or any other person may only give a motion. However, this activity does not initiate the proceedings (as opposed to a request), but merely alerts the competent administrative authority that there may be prerequisites for initiating proceedings. It is then up to the administrative authority to evaluate the information obtained by the party or some third person, and to initiate proceedings ex officio (for more details, see Večeřová, 2021, p. 28 et seq.). The problem arises, however, in a situation where the administrative authority assesses that there are no conditions or grounds for initiating ex officio proceedings and therefore does not initiate proceedings, but the person (party) does not agree with this and considers that the administrative authority is illegally inactive.

In such a situation, protection may be sought under $\S 80$ of the Administrative Procedure Code (Večeřová, 2020, p. 137 et seq.). However, if this procedure does not lead to a remedy, the question arises whether the action for protection against inaction can subsequently be brought. The case law in this respect takes a broadly uniform (negative) view, according to which the inaction action cannot be brought to require the

\footnotetext{
${ }^{10}$ Supreme Administrative Court of the Czech Republic, No. 7 Aps 3/2008-98 (16 November 2010).

11 Supreme Administrative Court of the Czech Republic, No. Ans 4/2004-116 (15 December 2004).

${ }^{12}$ Here it is necessary to proceed in accordance with $\S 65$ et seq. of the Code of Administrative Justice.

${ }^{13}$ Supreme Administrative Court of the Czech Republic, No. 4 Ans 8/2009-71 (29 October 2009).

14 Supreme Administrative Court of the Czech Republic, No. 2 Azs 193/2017-37 (3 August 2017).

15 For more detail about a null decision, see Frumarová (2014, p. 496).
} 
administrative authority to initiate proceedings but only to issue a decision on its merits or a certificate in proceedings already initiated'. ${ }^{16}$ Thus, such an action cannot be brought successfully where the legislation does not require the administrative authority to issue a decision on the matter (or a certificate), particularly where the submission is merely a motion and not a request. ${ }^{17}$

Despite the above conclusion, however, the Supreme Administrative Court has stated on several occasions in the past that there are some exceptional cases in which the action against inaction can be successfully brought. This is because if a person initiates an ex officio proceedings, and he or she has a public subjective right enshrined in the Charter of fundamental rights and freedoms or in the international human rights treaties that is to be litigated (condition 1), and at the same time the person cannot pursue his or her claim or the protection of his or her claim by other legal means, (condition 2), then an action can be brought. ${ }^{18}$

However, in its relatively recent decision the Extended Chamber of the Supreme Administrative Court again confirmed by majority an opinion that it is not possible to seek to initiate administrative proceedings ex officio by means of the action for inaction. In essence, it merely briefly stated that the motion cannot in itself initiate any administrative proceedings. ${ }^{19}$

In agreement with the extended Chamber, I consider that the current wording of the Code of Administrative Justice (§ 79) does not really allow a party to seek this type of protection through this kind of action, i.e. to impose an obligation on the administrative authority to initiate proceedings ex officio. Its possible use in the exceptional cases mentioned above is also very questionable. The point is that the Code of Administrative Justice provides for its application only in cases where administrative proceedings have already been initiated (whether at the request or ex officio). However, the proceedings have not been initiated by a motion, so one of the basic conditions for such an action is not fulfilled. At the same time, it is questionable what the court's ruling, if any, would be if we were to allow the possibility of bringing an action for failure to act. The Code of Administrative Justice provides that the court shall order the administrative authority to issue a decision and shall set a reasonable time limit for doing so. It does not speak of the imposition of an obligation to initiate proceedings.

It should be added that relatively recently a rather "revolutionary" decision was issued by the Supreme Administrative Court which allowed the use of an interference action for such situations, however under certain strict conditions. ${ }^{20}$ A person who has initiated the proceedings may bring an action for intervention and request the initiation of ex officio proceedings under the following conditions: the unlawful state which the proceedings are intended to remedy directly affects the substantive rights of the claimant and, at the same time, the claimant must have no other remedy available to them within the public administration or administrative justice system or must have unsuccessfully exhausted it (Frumarová, 2021, pp. 430-435).

\footnotetext{
${ }^{16}$ Supreme Administrative Court of the Czech Republic, No. 4 Ans 10/2006-59 (26 June 2007), Supreme Administrative Court of the Czech Republic, No. 8 Ans 1/2008-170 (31 March 2009), Supreme Administrative Court of the Czech Republic, No. 4 Ans 6/2006-162 (30 August 2007), or Supreme Administrative Court of the Czech Republic, No. 3 Ans 2/2007-64 (13 December 2007).

17 Supreme Administrative Court of the Czech Republic, No. 8 Ans 1/2008-170 (31 March 2009).

18 Supreme Administrative Court of the Czech Republic, No. 5 As 39/2008-46 (29 August 2008), similarly Supreme Administrative Court of the Czech Republic, No. 8 As 19/2008-50 (12 May 2009).

${ }^{19}$ Supreme Administrative Court of the Czech Republic, No. 6 As 108/2019-39 (26 March 2021)

${ }^{20}$ Ibidem.
} 
I believe that the distinction between administrative proceedings in terms of how they are initiated (on request versus ex officio) has its tradition, but above all, it has its essence and purpose. The opinion of the Supreme Administrative Court carries the danger of relativising this dichotomy and opens up room for reflection as to whether ex officio proceedings do not in fact become claim proceedings. Moreover, by doing so, the judicial power interferes quite significantly with the competence of the administrative authorities, since it is the administrative authorities, not the courts, which are entrusted with the special laws related to the determination of whether or not to initiate administrative proceedings. On the other hand, even in proceedings initiated ex officio, it is often not only objective law that is the subject of protection but also the subjective rights of a particular person. It is therefore understandable that the administrative courts seek to provide protection for those persons. This need is not only pointed out in practice, but also by doctrine, e.g. D. Codl in his article also supports the "open access to judicial protection" (2021, p. 64).

\section{STANDING AND TIME LIMIT FOR BRINGING AN ACTION}

The person who claims that the failure to act interferes with his or her legal sphere is the one who has an active standing to bring an action for failure to act. ${ }^{21}$ However, whether the administrative authority was in fact inactive is examined by the court only during the proceedings. Accordingly, a finding that an administrative authority has failed to act presents grounds for dismissing the action (a decision on its merits), not for rejecting it (a procedural decision). ${ }^{22}$

As regards the passive standing, the law (Code of Administrative Justice) provides that the defendant is the administrative authority which, according to the claim, is obliged to issue the decision or a certificate. Passive standing is therefore determined by the applicant's allegations in the application. However, the existence of an obligation on the part of the defendant to issue a decision or a certificate is dealt with by the administrative court only when it considers the substance of the application and not when it decides on procedural issues. The incorrect designation of the defendant therefore leads to the dismissal of the action, not to its rejection. The applicant's position is more complicated here than in proceedings against a decision, which are differently structured in that respect. In proceedings for failure to act, the responsibility for correctly identifying the defendant rests with the applicant. However, the courts have sought to 'mitigate' this potentially problematic aspect in practice. This is because the courts rely on the so-called 'procedural paternalism'. ${ }^{23}$ The court notifies the plaintiff that they have misidentified the defendant and only after the plaintiff fails to respond to this notification are there negative procedural consequences (dismissal of the action). ${ }^{24}$ In my view, the case law in question is clearly positive since it contributes to the fulfilment of the right to judicial protection against unlawful conduct or, in this case, unlawful inaction by the public authorities.

The time limit for bringing an action is one year. If a time limit is set for the decision of the administrative authority, there are no problems in determining the start of the time limit for bringing an action. However, if the law does not provide for a specific time limit for the decision, the action may be brought within one year from the date on

\footnotetext{
${ }^{21}$ Supreme Administrative Court of the Czech Republic, No. 1 Ans 5/2008-104 (2 July 2008).

22 Supreme Administrative Court of the Czech Republic, No. 5 As 86/2015-42 (26 July 2016).

${ }^{23}$ Supreme Administrative Court of the Czech Republic, No. Nad 224/2014-53 (9 December 2014). See also Kühn, Kocourek, et al. (2019, pp. 672-673).

${ }^{24}$ Supreme Administrative Court of the Czech Republic, No. 1 Ans 5/2007-195 (14 November 2007).
} 
which the last act was done by the applicant against the administrative authority or by the administrative authority against the applicant. The problem is that the Code of Administrative Justice does not specify which acts are considered relevant in this respect. However, it is possible to draw on case law which considers them to be the socalled procedural acts, either of the parties to the proceedings or of the administrative authority. ${ }^{25}$ Such a procedural act is, for example, an application to initiate proceedings, an appeal against a decision, summoning a party, serving a decision, and so on. On the other hand, the urgency of a case cannot be considered as such a procedural act. ${ }^{26}$ That view can be accepted since otherwise a new time limit for bringing an action would begin to run with each urgent application which would in effect negate the purpose of the time limit for bringing an action.

\section{CONDITIONS FOR BRINGING THE INACTION ACTION BEFORE COURT}

In addition to the general conditions of the proceedings, the specific conditions related exclusively to the action for failure to act must be satisfied. The complainant must:

1) claim the inaction of the administrative body and at the same time

2) exhaust the means of protection against this inaction, which must be a) generally stipulated by law and at the same time b) exhausted to no avail.

The judicial protection is built on the principle of subsidiarity. This means that the control of public administration activities should always be primarily provided by the public administration itself. If such a procedure is unsuccessful, the judicial protection should be implemented. The complainant is therefore obliged to exhaust the means provided by the procedural regulation valid for proceedings before an administrative body to protect him/her against the inaction of the administrative body. This condition must be met by the date on which the action is brought before the court. If this condition is not met when the action is brought, the action is inadmissible and the court will dismiss it as such. This means is a request for the application of measures against an inactivity pursuant to $\S 80$ of the Administrative Procedure Code. ${ }^{27}$ This provision allows a superior administrative authority to take remedial action in the situation of inaction by a subordinate administrative authority. The superior authority may issue a remedial order, make an attraction or delegation or extend the time limit for issuing a decision.

The issue of the need to apply $\S 80$ of the Code of Administrative Procedure in relation to the inactive ministries and other central administrative authorities was a bit problematic. The courts have not required this condition to be met for a long time as these administrative bodies do not have a superior body. And the government of the Czech Republic cannot be considered such a body. Nevertheless, after several years of this practice, the Supreme Administrative Court took the opposite view and now the party to the proceedings is obliged to exhaust the application pursuant to $\S 80$ of the Administrative Procedure Code even in situations when the complainant seeks protection against the inaction of the central administrative authority. ${ }^{28}$ It is a question for discussion whether this was a step in the right direction. In the case of inaction by the ministry, the minister himself, as the head of that body, should take action against inaction. However, it must be asked to what extent this person is separate from the

\footnotetext{
25 Supreme Administrative Court of the Czech Republic, No. 8 Ans 3/2005-107 (12 June 2006).

${ }^{26}$ Ibidem.

27 Supreme Administrative Court of the Czech Republic, No. 7 Ans 1/2007-100 (18 October 2007).

${ }^{28}$ Supreme Administrative Court of the Czech Republic, No. 8 Ans 2/2012-278 (20 May 2014).
} 
ministry, i.e. to what extent the person being inspected and the person inspecting are different. It may be questioned whether such a procedure makes sense and whether it would not be more appropriate to apply directly to the courts.

The above-mentioned means must be used to no avail. In practice, this can present several situations. On the one hand, the superior administrative body to which the party to the proceedings turned with their application for protection against the inactivity may also remain inactive. The question is at what point this body becomes inactive. The law does not explicitly state anything about this. The case law concludes that this is a period of 30 days, which is set as the basic time limit for issuing a decision under the Code of Administrative Procedure $(\S 71) .{ }^{29}$ The ineffectiveness can also lie in a situation where the superior administrative body takes measures against inactivity but the subordinate administrative body still remains inactive. Finally, this can include a situation in which the superior administrative body does not comply with the request.

Another condition of proceedings on this action is the fact that a special law does not connect the inaction of an administrative authority with the legal fiction that a decision with certain contents has been issued or with another legal consequence. According to the legislator, the fiction of a decision, whether positive or negative, is a sufficient means of legal protection against inaction. If a party is dissatisfied with such a fictitious decision (which will certainly be in the case of a fictitious negative decision), he or she can, of course, seek judicial protection, however not by bringing an action for failure to act but by bringing an action against the administrative decision.

\section{COURT DECISION ON THE COMPLAINT}

The regional courts are materially competent to decide on the inaction actions. The decision is made by a senate (not by a single judge), regardless of what is involved in the proceedings in which the administrative body failed to act. The inactive complaints are among the cases that are discussed and decided as a matter of priority ( $\S 56$ of the Code of Administrative Justice).

The court decides according to the facts established on the date of its decision. This means that the administrative authority's inaction must still persist at this time. Even if the court finds the inaction, it must further examine whether it is attributable to the administrative body (the so-called material corrective). It is very important because the party to the proceedings may also be liable for inaction. ${ }^{30}$

If the court concludes that the action is well founded, it will impose an obligation on the administrative authority to issue a decision or a certificate. It should be emphasized that the court cannot determine the content of the decision in its decision as this would violate the principle of the separation of powers (Article 2 of the Czech Constitution). ${ }^{31}$ Such a rule applies without any problem to inaction in deciding a case but in the case of inaction concerning non-certification, the situation is somewhat different as the court will have to break the boundary and impose an obligation on the administrative authority issuing a certificate of certain content. ${ }^{32}$

An obligatory part of the judgment is also the setting of time limit for issuing a decision (or a certificate). This time limit should be reasonable, so it must be based in particular on the complexity of the case and other circumstances of the case that have

\footnotetext{
${ }^{29}$ Supreme Administrative Court of the Czech Republic, No. 2 Ans 14/2012-41 (10 December 2012).

30 Ibidem.

${ }^{31}$ Supreme Administrative Court of the Czech Republic, No. 7 Afs 33/2003-80 (30 September 2004).

32 For more details see Jemelka et al. (2013, p. 690 et seq.).
} 
been identified. This time limit may not be longer than the limit stipulated by a special law. If the court concludes that the action is unfounded, it will dismiss it.

A cassation complaint ( $§ 102$ et seq. of the Code of Administrative Justice) may be filed against a final judgment of a regional court. The cassation complaint is decided by the Supreme Administrative Court. The subject of ambiguity and various interpretations $^{33}$ was the question of whether the administrative body will issue a decision as imposed by a final judgment of the regional court, will not make the cassation complaint filed by it groundless (because the administrative body is no longer inactive). The Enlarged Chamber of the Supreme Administrative Court stated in its resolution that "the subject of the cassation complaint procedure is the decision of the regional court, not the inaction of the administrative body (which was the subject of the proceedings before the regional court). ${ }^{134}$ Thus, even if the administrative body issues a decision in the meantime, this is not an obstacle to the hearing of the cassation complaint.

The last problematic aspect that I would like to mention is the fact that the Code of Administrative Justice does not give the power to the courts to subsequently monitor compliance with the obligations imposed. The courts cannot therefore check whether the administrative authorities have actually issued the decision or a certificate. The courts also do not have the possibility to impose a sanction, for example in the form of fines. However, the complainant has the opportunity to apply for the enforcement of the decision by a court or a bailiff. He can also seek damages or a non-pecuniary damage for maladministration. ${ }^{35}$

\section{CONCLUSION}

In summary, the legal regulation of the action for protection against inaction is undoubtedly one of the benefits of the current administrative justice system. I believe that protection against the inaction by administrative authorities should constitute one of the competences of the administrative judiciary in any democratic state governed by the principle of the rule of law. Nevertheless, there are certain problems, or at least questions for reflection, associated with the legal regulation of inaction actions and their application in practice.

First, there is a need to discuss whether the current "dual" concept of judicial protection against the inaction is appropriate. The fact is that if an administrative authority is inactive, an action for inaction should be brought in some cases and an action for protection against unlawful interference in other cases. In my view, consideration should be given to simplifying this system of judicial protection. A solution could be to formulate the regulation of inaction actions more broadly in the Code of Administrative Justice. At present, the failure to act must consist of a failure to issue a decision on the merits or a failure to issue a certificate. De lege ferenda, the regulation could be worded in such a way that the plaintiff could seek protection in the case of failure to issue a decision or to carry out another act provided for by the law.

Another issue for discussion concerns the fact that there is a very limited possibility of seeking the initiation of administrative proceedings ex officio in the administrative justice system. An inaction action cannot be used at all in such cases.

\footnotetext{
${ }^{33}$ Supreme Administrative Court of the Czech Republic, No. 5 Ans 1/2005-54 (August 2005), or Supreme Administrative Court of the Czech Republic, No. 8 Ans 1/2006-135 (15 August 2006).

${ }^{34}$ Supreme Administrative Court of the Czech Republic, No. 8 Ans 1/2006-135 (15 August 2006).

${ }^{35}$ Act No. 82/1998 Coll., on Liability for Damage Caused in the Exercise of Public Authority by Decision or Improper Official Procedure.
} 
More recently, however, the Supreme Administrative Court has admitted the possibility of using an action for intervention in such a case, provided that several strict conditions are met. In my view, this is a very contentious issue. As a result of the conclusions of the Supreme Administrative Court, the meaning of the distinction between administrative proceedings initiated on request and ex officio may be negated. On the other hand, the efforts to extend judicial protection in favour of individuals should be supported. I think that the Slovak legislation may present suitable inspiration for the Czech legislation de lege ferenda. The Slovak Code of Administrative Justice allows the public prosecutor to bring an action for inactivity to initiate administrative proceedings ex officio ( $\S 242$ ). I consider the prosecutor's standing to sue to be a more appropriate solution than conferring such standing on all natural and legal persons. They are people with specialist knowledge and limiting standing to the public prosecutor alone does not negate the essence of the ex officio administrative procedure to such an extent.

A certain problem of the Czech legislation is also the question of the enforceability of court decisions. It is that Czech administrative courts do not have the power to control the execution of their judgments, nor do they have sanctioning powers in this respect. I believe that this weakens the protective function of the administrative judiciary. De lege ferenda, it would be advisable to consider taking inspiration from the Slovak legislation again. The Slovak Code of Administrative Justice allows the administrative court to impose a fine on an administrative authority in the situation when the administrative authority fails to remedy the failure within the time limit set by the court (§ 251). I believe that introducing similar competences of administrative courts into the Czech legislation would strengthen the effectiveness of judicial protection against the inaction of the public administration.

In spite of the above-mentioned shortcomings, the legal regulation of inactivity actions can be assessed positively. This institution has significantly contributed to the protection of public subjective rights of the addressees of public administration. De lege ferenda, however, it would be advisable to consider making some changes which would strengthen the effectiveness and functions of this judicial protection.

\section{BIBLIOGRAPHY:}

Codl, D. (2021). Zamyšlení nad stávajícím pojetím veřejných subjektivních práv jakožto základu aktivní žalobní legitimace v soudním řízení správním. Právnik, CLX(1), 51-64.

Frumarová, K. (2003). Nezákonná nečinnost ve veřejné správě a význam institutu „přiměřené lhůty" ve vztahu k nezákonné nečinnosti veřejné správy. Správní Právo, 36(1), 1-13.

Frumarová, K. (2012). Ochrana před nečinností veřejné správy. Praha: Leges.

Frumarová, K. (2014). Nicotnost správního rozhodnutí. Praha: Leges.

Frumarová, K. (2021). Správněsoudní ochrana v případě nezahájení správního rízení ex offo. Právní Rozhledy, 29(13-14), 430-435.

Frumarová, K., Grygar, T., Pouperová, O., and Škurek, M. (2021). Správní právo procesní. Praha: C. H. Beck.

Jemelka, L., Podhrázký, M., Vetešník, P., Zavřelová, J., Bohadlo, D., and Šuránek, P. (2013). Soudní rád správní. Praha: C. H. Beck.

Kühn, Z., Kocourek, T., et al. (2019). Soudní rád správní. Komentář. Praha: Wolters Kluwer.

Pomahač, R. (2002). Modality obecné správní žaloby. Justiční Praxe, (3), 100 et seq. 
Potěšil, L., Šimíček, V. et al. (2014). Soudní raád správní. Komentár. Praha: Leges.

Skulová, S. et al. (2020). Správní právo procesní (4th edition). Plzeň: Aleš Čeněk s.r.o.

Srebalová, M. (2008). Rýchlost' správneho konania a nečinnost' správneho orgánu. Bratislava: Právnická fakulta UK.

Varvařovský, P., and Holeček, M. (2001). K vydání nálezu ÚS, kterým se zrušuje část pátá „Správní soudnictví" OSŘ. Právní Zpravodaj, (5), 9-10.

Večeřová, S. (2020). Opatření proti nečinnosti v případě nezahájení správního řízení z moci úřední. Správní Právo, (3), 137-148.

Večeřová, S. (2021). Vyřizování podnětu k zahájení správního řízení z moci úřední. Jurisprudence, (2), 28-36.

Act No. 82/1998 Coll., on Liability for Damage Caused in the Exercise of Public Authority by Decision or Improper Official Procedure.

Act No. 500/2004 Coll., Administrative Procedure Code.

Act No. 150/2002 Coll., Code of Administrative Justice.

Charter of Fundamental Rights and Freedoms.

Constitution of the Czech Republic (Act No. 1/1993 Coll.).

Convention for the Protection of Human Rights and Fundamental Freedoms.

Czechia, Constitutional Court of the Czech Republic, No. I. ÚS 5/96 (5 November 1996).

Czechia, Constitutional Court of the Czech Republic, No. IV. ÚS 114/96 (25 September 1997).

Czechia, Constitutional Court of the Czech Republic, No. II. ÚS 366/96 (1 October 1997).

Czechia, Constitutional Court of the Czech Republic, No. III. ÚS 218/97 (4 December 1997).

Czechia, Constitutional Court of the Czech Republic, No. IV. ÚS 559/2000 (9 November 2000).

Czechia, Constitutional Court of the Czech Republic, No. PI. ÚS 16/99 (27 June 2001).

Czechia, Constitutional Court of the Czech Republic, No. IV. ÚS 690/01 (27 March 2003).

Czechia, Constitutional Court of the Czech Republic, No. III. ÚS 687/04 (5 October 2005).

Czechia, Constitutional Court of the Czech Republic, No. II. ÚS 507/05 (4 January 2006).

Czechia, Supreme Administrative Court of the Czech Republic, No. 7 Afs 33/2003-80 (30 September 2004).

Czechia, Supreme Administrative Court of the Czech Republic, No. Ans 4/2004-116 (15 December 2004).

Czechia, Supreme Administrative Court of the Czech Republic, No. 5 Ans 1/2005-54 (August 2005).

Czechia, Supreme Administrative Court of the Czech Republic, No. 8 Ans 3/2005-107 (12 June 2006).

Czechia, Supreme Administrative Court of the Czech Republic, No. 8 Ans 1/2006-135 (15 August 2006).

Czechia, Supreme Administrative Court of the Czech Republic, No. 4 Ans 10/2006-59 (26 June 2007).

Czechia, Supreme Administrative Court of the Czech Republic, No. 4 Ans 6/2006-162 (30 August 2007).

Czechia, Supreme Administrative Court of the Czech Republic, No. 7 Ans 1/2007-100 (18 October 2007).

Czechia, Supreme Administrative Court of the Czech Republic, No. 1 Ans 5/2007-195 (14 November 2007).

Czechia, Supreme Administrative Court of the Czech Republic, No. 3 Ans 2/2007-64 (13 
December 2007).

Czechia, Supreme Administrative Court of the Czech Republic, No. 1 Ans 5/2008-104 (2 July 2008).

Czechia, Supreme Administrative Court of the Czech Republic, No. 5 As 39/2008-46 (29 August 2008).

Czechia, Supreme Administrative Court of the Czech Republic, No. 8 Ans 1/2008-170 (31 March 2009).

Czechia, Supreme Administrative Court of the Czech Republic, No. 8 As 19/2008-50 (12 May 2009).

Czechia, Supreme Administrative Court of the Czech Republic, No. 4 Ans 8/2009-71 (29 October 2009).

Czechia, Supreme Administrative Court of the Czech Republic, No. 7 Aps 3/2008-98 (16 November 2010).

Czechia, Supreme Administrative Court of the Czech Republic, No. 2 Ans 14/2012 (10 December 2012).

Czechia, Supreme Administrative Court of the Czech Republic, No. 2 Ans 14/2012-41 (10 December 2012).

Czechia, Supreme Administrative Court of the Czech Republic, No. 8 Ans 2/2012-278 (20 May 2014).

Czechia, Supreme Administrative Court of the Czech Republic, No. Nad 224/2014-53 (9 December 2014).

Czechia, Supreme Administrative Court of the Czech Republic, No. 5 As 86/2015-42 (26 July 2016).

Czechia, Supreme Administrative Court of the Czech Republic, No. 2 Azs 193/2017-37 (3 August 2017).

Czechia, Supreme Administrative Court of the Czech Republic, No. 6 As 108/2019-39 (26 March 2021). 